\title{
Technology Transfer Model Proposal in Public Research Institutions: The Search for a more Effective Process in the Broiler Chain in Brazil
}

\author{
Nádia S. Schmidt Bassi ${ }^{1},{ }^{3}$ Christian Luiz da Silva ${ }^{2}$, Elsio Antonio P. de Figueiredo ${ }^{3}$
}

Summary: Brazilian agricultural and livestock represent 22.54\% of the Brazilian Gross Domestic Product. The Brazilian Agricultural and Livestock Research Company aims to develop technologic solutions for this sector. It has an approximate annual budget of 2.5 million dollars and 2,440 researchers. The researches target audience diversity makes more challenging the Technology Transfer process for the institution. The objective of this article was the proposal and validation, under the perception of the broiler productive chain agents, of a Technology Transfer model to optimize the public-private interaction for the institution. Were interviewed 142 agents, with a statistically significant sample, higher than $95 \%$. The results demonstrated the contribution of Embrapa for the technological development of the chain is perceived as low, but the Technology Transfer model presented was considered essential by $96.77 \%$ of the respondents to optimize the Technology Transfer of Embrapa Pigs and Poultry to the chain.

Keywords: Public Research Institutions; Embrapa; Technology Transfer; Broiler productive chain.

Submitted: August 26th 2015 / Approved: December 8th 2015

\section{Introduction and objectives}

For Schwartzmann (2002), we are before an important paradox: Brazil spends most of its public research resources in applied activities, but the results are not used nor appear as they should appear. For the author, this situation derives from the existence of a strategy among researchers of basic areas, "of presenting their projects as if they were applied, to obtain more funds" (Schwartzmann, 2002, p.386).

Considering that the transfer of the technologies generated in the IPPs is the consecration of all the energy spent for the knowledge generation and the security of the research validity, via technology adoption, is admitted that among the limiting factors for adoption of the generated technologies is their transfer form (Schaun, 1981). The comprehension of that problem goes unquestionably for the need of executing a technology transfer strategy in which prevail now forms of relationship among the diverse actors of these processes. Besides that, Wildner et al (1993), highlights that must be considered the possibility that the generated technology may not be in concordance with the reality of the social system that wants to be modified, due to, mainly, the lack of integration among research-user.

In this context, the Brazilian agricultural and livestock represented in 2013 22.54\% of the Brazilian Gross Domestic Product (CEPEA, 2015) and Embrapa (Brazilian Company of Agricultural and Livestock Research) is the IPP responsible for developing technological solutions for Brazilian agricultural and livestock. This institution has an approximate budget of 2.5 million dollars per year and employs
2,440 doctor researchers, but the diversity of the target audience of the developed researches turns the Technology Transfer process into a great challenge for the institution. Embrapa operates through 46 decentralized research units. Each unit is focused in a specific product or service. For this research was decided to study the TT process of the unit called Embrapa Pigs and Poultry, which develops researches for the Brazilian poultry and pig chains.

The objective of this article was the proposal and validation, under the perception of the agents involved in the chain, of a technology transfer model to optimize the public-private interaction for the institution.

The model presented in this research aims to promote a higher interaction of Embrapa Pigs and Poultry with the chain, to know its research demands, which also may subsidize other public institutions working with knowledge and technology transfer for innovation in products and services.

This article is composed of this Introduction (section 1), followed by four more sections. Section 2 presents the survey methodology. Section 3 is a summary about the technology transfer process in public institutions, followed by section 4 which presents the characteristics of Embrapa and its TT process. The fifth section presents Embrapa Pigs and Poultry and its TT process. The sixth section brings the details of the proposed technology transfer model, followed by the survey results and, finally, the conclusion of the work, in the eighth section.

1 UTFPR (Universidade Tecnológica Federal do Paraná), Brazil.

2 Programa de Pós-graduação em Tecnologia, UTFPR, Brazil.

3 Embrapa, Brazil.

*Corresponding author: nadia.bassi@embrapa.br 


\section{Methodology}

To validate the proposed TT model was elaborated a register of the companies related to the broiler productive chain. For that, was used the industrial aviculture Gessulli Guide, available at: http://www. guiagessulli.com.br/.

The register was divided in five links: Agricultural industries, Equipments, Genetics, Nutrition and Health. Besides that register, was searched with the researchers of the aviculture area of Embrapa Pigs and Poultry, suggestions of people which may significantly contribute to the survey. Thereby, the selection criteria of those agents, was made in two forms: the Industrial Aviculture Gessulli Guide and the indication of researchers of the area. The production and industrialization segments of the broiler productive chain were selected due to the fact that most researches made by Embrapa Pigs and Poultry are targeted to these two segments.

The interview script was elaborated from the information obtained by the literature analysis, of internal institution documents and analysis of the institution technology transfer process, made in previous researches. In the elaboration, we tried to evaluate the knowledge and the perception of the respondents regarding the issues in question besides of linking theoretical aspects presented in this work.

For dealing with the information obtained in the semi-structured interviews, was made a qualification by group of issues addressed. For the analysis of the answers, the questions were divided in five groups (Table 1).

Table 1 - Qualification of the groups by issues addressed Groups

Survey protocol questions

\begin{tabular}{l|l}
\hline Characterization of the respondents and company & $\begin{array}{l}\text { Nome of the respondent; Company; Sector of activity; Position, Range of the } \\
\text { company, Nr. of employees; Location; }\end{array}$ \\
\hline Contribution of Embrapa & $\begin{array}{l}\text { Technologies developed by Embrapa and adopted by the company; forms of } \\
\text { promoting more interaction with the chain, focus of RD\&I efforts. }\end{array}$ \\
\hline Relationship with IPPs & $\begin{array}{l}\text { Relationship difficulties with IPPs; best form for IPPs to develop efficient } \\
\text { technologies. }\end{array}$ \\
\hline Validation of the TT Model & $\begin{array}{l}\text { Agrees with the creation of an observatory; role of Embrapa in the } \\
\text { observatory; role of the companies of the observatory; links that must } \\
\text { participate; interaction forms of the observatory; formalization of the } \\
\text { observatory and participation in the observatory. }\end{array}$ \\
\hline Source: Own authorship &
\end{tabular}

Source: Own authorship

Were interviewed 142 agents, with direct involvement in the issues addressed by the survey. The questionnaires were sent using-se the program Lime Survey, in the period from November $20^{\text {th }}, 2014$ to February15 $5^{\text {th }}, 2015$.

The objective was to know the perception of the respondents regarding the contribution of Embrapa Pigs and Poultry to the chain and validate the TT model proposed for Embrapa Pigs and Poultry.

The type of sampling selected for the survey was the single randomized, in which all elements have the same probability to be selected. The formula used for the calculus of the random sample was indicated by Santos (2014):

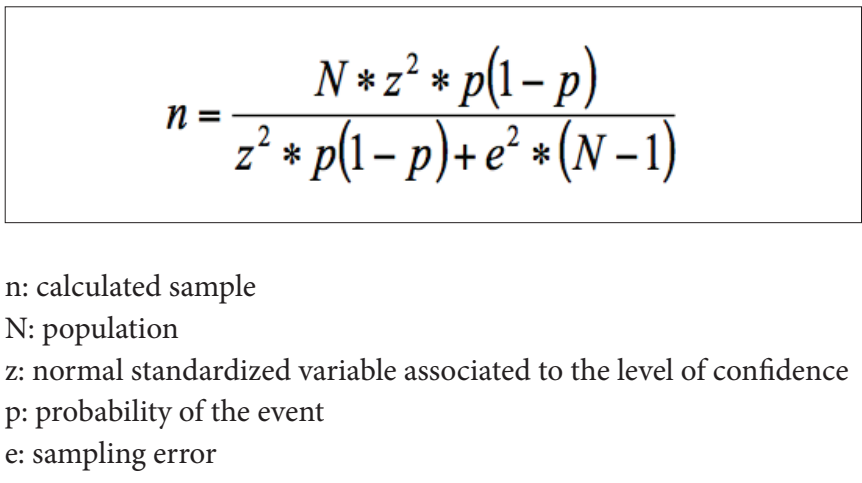


The sampling error attributed for the calculus was 5\%, with a level of confidence of $95 \%$ for a population of 190 persons. The number of the wished sample, therefore, was 142 respondents.

The pre-test of the questionnaire was made with 4 agents, with each one of them representative of a chain link. The selection of the pre-test integrants was made by the knowledge about the issues addressed, as well as by the proximity with the researcher. The pre-test helped in the adaptation of the questions vocabulary and insertion of explicative notes in technical terms unknown by the respondents, as well as for measuring the estimated answer time of the questionnaire. Considering that there was not any variable modification, all the answers were incorporated as valid.

\section{Technology transfer in public research institutions}

In Schaun's (1981) opinion, the technology transfer is the consecration of all the energy spent for the generation of the knowledge and the security of the research validity, by means of technology adoption. Among the limiting factors for the adoption of the generated technologies, are the transfer form and the possibility that the generated technology is not in concordance with the reality of the social system that wants to be modified, due to, mainly, the lack of integration among research-user (Wilder et al., 1993).

In this sense, Fujisaka (1994) enumerates a series of reasons why the technologies generated are not adopted and among which, that the technology results from a poorly formulated problem by the research, in other words, the users do not have the problem that the researchers assumed. This ascertainment leads to the need of setting a "two-way" communication process, in other words, the integration among the diverse actors involved in the technologic innovation process, aiming to facilitate the technology adjustment to the conditions prevailing in the productive unit (Tagliari, 1984).

In that context, Schwartzmann (2002) affirms that we are before an important paradox: Brazil spends most of its research resources in applied activities, but the results are not used nor appear as they should appear. For the author, this situation derives from the existence of a strategy, among researchers of basic areas, "of presenting their projects as if they were applied, to obtain more funds" (Also exists other scenario in which the research is made with applied objectives, but its results are never applied). According to the author:

This is also a known situation, which receives the name of "shelf research": the work advances until the elaboration of a prototype, for example, or of a pilot project, but never transforms into a tradable product, or into an operational and practical procedure, in the private sector, or in the public sector (Schwartzmann 2002, p. 386).

For Schwartzmann (2002), there are several possible reasons for this situation, but, the most common is that, despite of the intentions of researchers and financing agencies in producing applicable and profitable results, there are no buyers or users for these results.

Agricultural technologies, according to Atkinson et al. (2003), repre- sent a special challenge for the technology transfer programs of the public institutions which must balance the objectives of technology commercialization with the social and financial objectives. According to Pineiro (2007), the IPPs must join forces with the private sector to finance resource sources and trained personnel, as the agricultural and livestock innovation always happens collaboratively among public institutions, the scientific community and researchers. Considering the growing importance of the private sector in the innovation process, the challenge of the public sector is to work with these new players (Pineiro, 2007).

Several authors (Krieger and Galembeck,1990; Schwartzmann, 2002; Kim, 2005; Póvoa, 2008, among others) highlight the absence of a link between researchers and companies' professionals and the need of having a tightening of the relationship between both for they to work in a more integrated form aiming to present efficient solutions for the existing problems.

In this context, the proposed model was built with the objective of meeting those needs, besides of considering the peculiar characteristics of the broiler productive chain and of Embrapa, as a public research institution.

\section{Embrapa}

Brazilian Agricultural and Livestock Research Company was created in April 26 $6^{\text {th }}, 1973$ and is linked to the Agriculture, Livestock and Supply Ministry (MAPA). To accomplish its mission of enabling solutions of research, development and innovation for the sustainability of agriculture, in benefit of the Brazilian society, operates as a network, with 17 Administrative Units located in Brasília/DF, and 46 Decentralized Research Units, 16 business offices, distributed in several regions of Brazil (Embrapa, 2008).

With partnerships in the USA, France, Germany, England, South Korea, China and Japan (in phase of implantation), with the objective of generating new knowledge for development of innovative technologies, promoting opportunities of international cooperation in agricultural and livestock research, strengthening research networks and monitor world tendencies. Also have projects in Africa, Venezuela, Central America and the Caribbean, with the objective of disseminate the developed technologies for those countries, aiming to expand the agricultural development (Embrapa, 2015).

Embrapa coordinates the National System of Agricultural and Livestock Research (SNPA), formed by federal and state public institutions, universities, private companies and foundations which, through cooperation, execute researches in the different geographic areas and scientific knowledge fields.

\subsection{Technology Transfer in Embrapa}

The TT process is coordinated by the Technology Transfer Executive Board, which have under its supervision the Technology Transfer Department -DTT, the Business Department - SNE and the Decentralized Units. 
The more used forms for transferring technologies and generated knowledge are:

- Technology diffusion, which is the appropriation by the target audience of knowledge exempt of intellectual protection, promoted by rural extension agents, technical assistance, diffusion networks, using field days, observation units, courses, lectures, publications and medias and

- Commercialization of technologies, which can be done by signing of contracts like: Use licensing; Alienation or direct sale; Providing of services (consultancies, Counseling, product tests).

Despite the Technology Transfer Department (DTT) systematizes the TT strategies with the Units, some sub-processes are coordinated by other departments and TT strategies are decentralized developed, directly by the research units.

The main instruments used for TT are the technical courses, field days, lectures, demonstrative and observation units, technological showcases, events, business plans, technical publications, radio and TV programs and mini-libraries.

The identification of the research demands is made for each unit, following a guiding document called Embrapa Directive Plan (PDE). Embrapa does not have an official TT model, only exist some already applied models for specific technologies.

Eldred and McGrath (1997), Garnica and Torkomian (2009) and Schaun (1981), point out the importance of a well-structured TT management process, with a clear definition of roles and responsibility for all involved employees, because the result transfer success, according to those authors, largely depends of clearly defined and managed methodologies.

\section{Embrapa Pigs and Poultry}

Embrapa Pigs and Poultry is a decentralized unit of the Brazilian Agricultural and Livestock Research Company. Its mission is to "Enable research, development and innovation solutions for the sustainability of pig farming and aviculture in benefit of the Brazilian society “.

Created in June $13^{\text {th }}, 1975$, to develop researches in the pig farming area. In 1978, also received the task of poultry research, receiving the name Pigs and Poultry National Research Center, called today Embrapa Pigs and Poultry.

Today, have a staff of 211 employees, formed by 51 researchers ( $86 \%$ doctors and 14\% masters), 55 analysts, 37 technicians and 68 assistants. The team of researchers is divided by area with: $36 \%$ in aviculture; $38 \%$ pig farming and $26 \%$ working in both areas. The unit budget varies according to the approved project portfolio. In 2014, the budget was R\$ 5.07 millions.

\subsection{Technology Transfer in Embrapa Pigs and Poultry}

Embrapa Pigs and Poultry uses the same instruments of Embrapa Head Office, in other words, the knowledge generated that is exempt of intellectual protection are transferred to the public by technical publications, Medias and technical events. The other technologies are transferred by contract.

The more used types of contract are the technical cooperation contracts - where the technology is developed in partnership with the private company, and then commercialized by it by means of a licensing of use contract; and the contracts for commercialization of technologies - when the technology is developed only by Embrapa, which transfers it to the partner to commercialize it, paying royalties on the sale. The unit also uses the consultancies providing of services modality, courses and trainings.

The TT process in the Unit include several areas, mainly the sectors of Technological Prospection and Evaluation (SPAT) and Technology Articulation and Implementation Sector (SPIT), which, due to the nature of the activities have the participation of employees of other sectors and, mainly, of the researchers.

A survey made in 2013 by Bassi and Silva (2013) with the professionals that work in the unit TT area, demonstrated that the elaboration of the TT strategies are not clearly defined, and, when they are outlined, are too specific, directed for specific projects and discussed without the participation of the transfer professionals.

Other factor appointed was the preoccupation of the professionals regarding the technologies developed by the Unit, which, according to the professionals, great part of them do not meet the chain demands.

Those facts point out the need of the creation of a mechanism allowing identifying the main demands of the chains in which the Unit is inserted, with the objective of developing proper solutions to meet those demands. Such a mechanism is essential, considering that the existence of demand for the technology or service is a required condition for the transfer, and the knowledge of the demand makes possible to identify the needs, guiding the research and development works.

\section{Technology transfer model proposed for Embrapa Pigs and Poultry}

The proposed model was created from the studies made about the TT concepts, mechanisms and models, the TT process in public research institutions, the characteristics and structure of the broiler productive chain and the contribution of the public research for that chain.

The main assumption is to increase the interaction between the developers of the technology and the users, suggesting the technology as a result of a two-way interactive process (non-linear) with constant and simultaneous exchange of ideas between the involved individuals. 
The proposal is based in the creation of an Observatory ${ }^{1}$, with strong interface in the centers that generate technological poultry innovations which are in the production and industrialization stages, where are located the companies of nutrition, genetics, health, machines and equipments and agricultural industries (Figure 1).

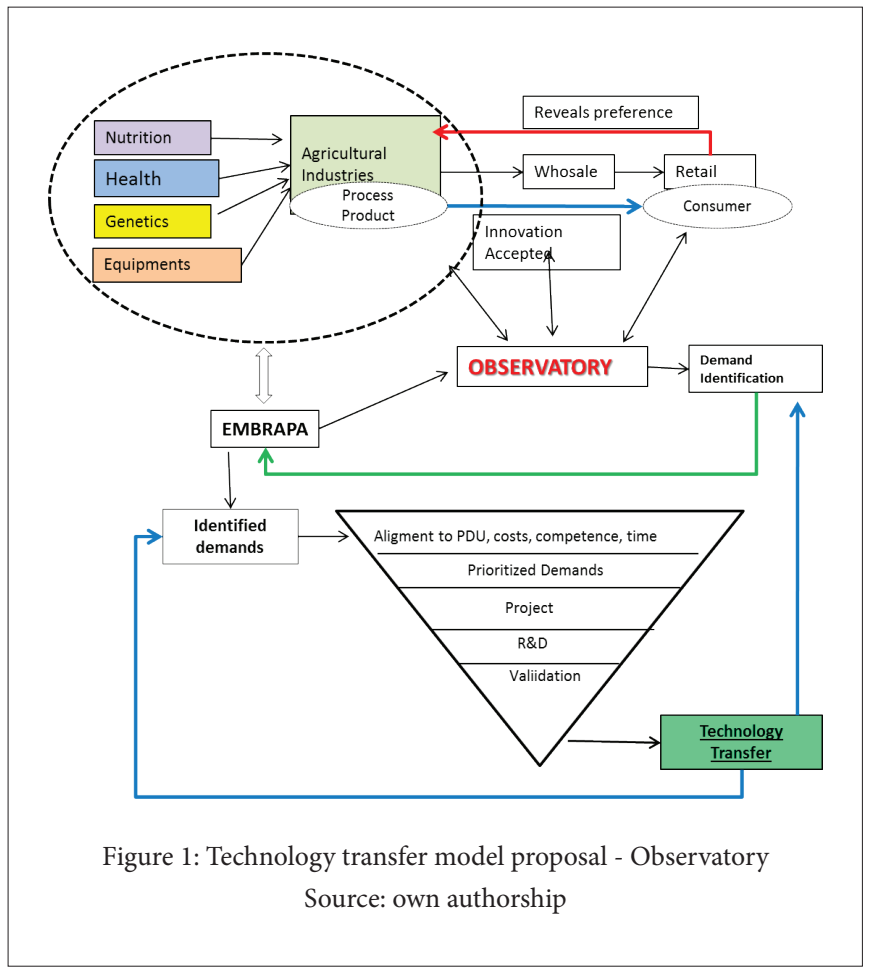

The model considers that Embrapa research activities are more strongly directed to production and industrialization stages, where there is an exchange of information between those agents. Thereby, starting from that interaction between the involved actors, the chain research demands would be identified in the observatory and transferred to Embrapa.

Is essential that the observatory team develops and keeps a strong and impartial interaction with the diverse links of the chain, with the objective of following the technological development and identify research demands. At the same time, must interact with the institution RD\&I personnel, looking for alternatives, solutions and suggestions, before the identified demands.

The identified demands in the observatory are transferred to Embrapa which will evaluate the feasibility of the research under the optic of the mission, costs, competencies and time.

From those premises, the demands will be prioritized and transformed in research projects, which after the development and vali- dation of the generated technologies, those will be transferred to the demanding users.

The adoption of that TT model will involve the use of the interactive innovation model, in other words, the definition of the project portfolio will be based in the demands pointed out by the chain. In that case, the TT role will no longer be the search for customers/users of the generated technologies, as they were developed to meet a specific demand or solve a specific problem of the user.

The new TT role of that model will be the consultation to customers, formalization of partnerships, distribution of royalties and technology patenting/licensing. That model proposes an interactive relationship between the links of the chain and the technical team and the leadership of Embrapa Pigs and Poultry. That approximation with the chain will allow knowing better the existing problems and discuss together the best form of solving them.

Thereby, knowing the problems of the chain and to develop practical solutions will help Embrapa to increasingly legitimate itself before the society.

\section{Results}

For a best understanding of the results, these will be presented in four subsections: characterization of the respondents and companies; relationship with IPPs; contribution of Embrapa to the chain; and validation of the model in fact demonstrates that, for being a part of the companies' strategic area, the surveyed public have knowledge of the addressed issue.

Most of the respondents work in the nutrition area (36.4\%), while the smaller percentage works in the genetics area (9\%). That fact is easily explained by the number of companies operating in those links, considering that the genetics companies are in a smaller number compared to the other segments (Figure 2).

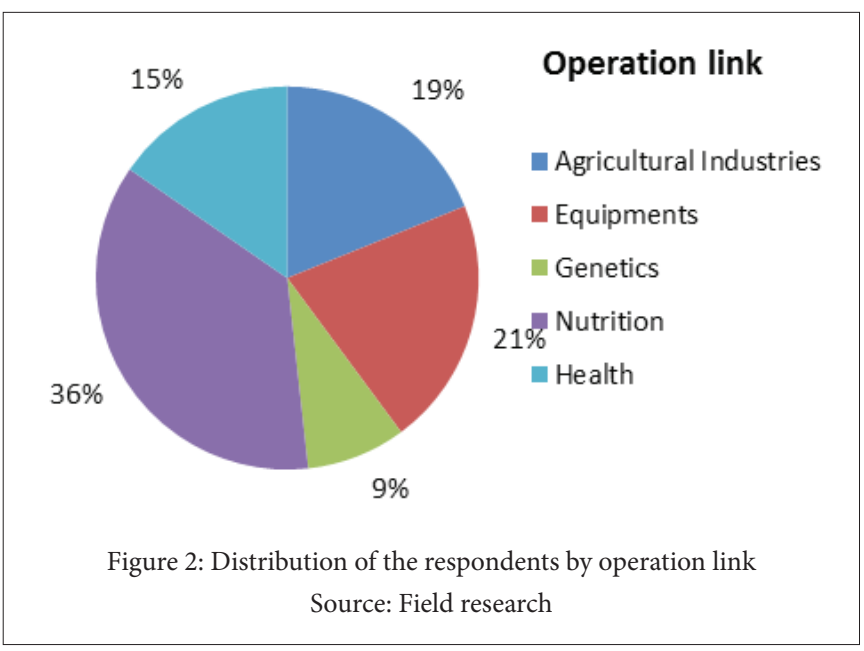

(1) Observation device created by organizations, to follow the evolution of a phenomenon, domain or strategic issue, in time and space. In the origin of an observatory must exist a problematic that can be translated in the form of objectives, which allow defining indicators, which calculus needs the data integration and allows the execution of synthesis (FIEP, 2014). 
Regarding the companies, $50.3 \%$ have international scope and $49.7 \%$ national scope. The link that has more companies with national scope is the agricultural industries link (due to the existence of a great number of small agricultural industries in Brazil), while most part of genetics companies $(66.77 \%)$ have international scope.

Regarding location, most part of the companies is located in the South $(48.25 \%)$ and southeast $(46.85 \%)$ regions. Considering that the south region is the largest producer of broilers and that the southeast region is the largest Brazilian industrial center, this result was already expected. Only nutrition companies are present in all Brazilian regions. The rest are concentrated in the south and southeast regions, with exception of health and agricultural industries which also have companies in the central-west region.

Regarding the staff, $24.48 \%$ of the companies have a staff of up to 50 employees. The equipment (40\%) and nutrition (32.70\%) companies are the ones that have the largest percentage of small companies (up to 50 employees). The nutrition and agricultural industries companies have the largest percentage of big companies, with more than 5,000 employees.

\section{Relationship of the chain with the Public Research Institutions}

The Brazilian government created several public institutions, with the intention of solving the social problems and promoting new knowledge, look for the Country's technological independence, besides of streamline the information transfer, reducing the time between the technology generation and adoption. Several authors point out the need of a tightening of the relationship between the IPPS and the private sector, to work in a more integrated form in the search for efficient solutions for the presented problems.

To analyze the relationship of the chain with Public Institutions were elaborated two questions: Which are the main difficulties in the partnership with IPPs and which is considered the best form for the IPPs to develop efficient technologies for the chain.

The main difficulties in the partnerships with the IPPs pointed out by the group of respondents are the excess of bureaucracy (74.5\%) and the slowness (62.4\%), as demonstrated in Figure 3.

Those two factors were mentioned as main difficulties by the respondents of the agricultural industries (81.50\% each), of equipments (82.50\% and $65.50 \%)$, of nutrition $(66.70 \%$ and $52.90 \%)$, of health (72.70\% and 59.10\%). The genetics link considers the excess of bureaucracy (75\%), different timing between companies and IPPs (66.70\%). Slowness was in third place for those companies (58.30\%).

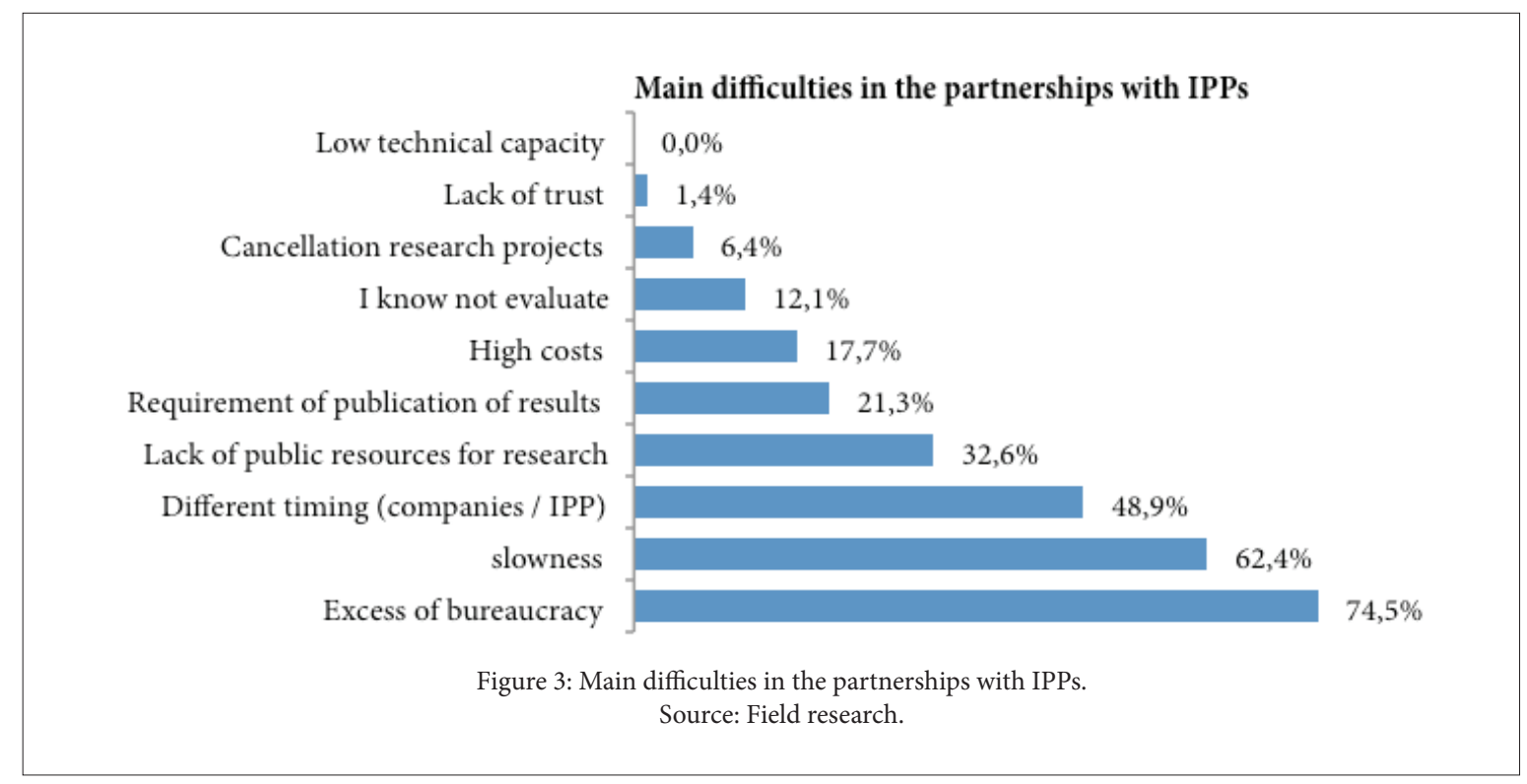

According to the interviewed group, the best form for the IPPs to develop efficient technologies for the chain is "To develop the technologies in partnership with the chain agents" (89.3\%).

Bureaucracy is one of the largest obstacles for economic growth of Brazil, according to the research of Grant Thorton International (2010), being mentioned as the largest barrier for $37 \%$ of the entre- preneurs, higher result than the world average (32\%) and emerging countries average (31\%).

Regarding slowness, Johnson (1996) affirms that the fact that property is public makes several processes more fragile, complex and slow, which can be simpler and more dynamic in the private organization, whose objectives are clearer and a smaller external control than the exercised in the public organization. 


\section{The contribution of Embrapa Pigs and Poultry to the broil- er productive chain}

To analyze the contribution of Embrapa Pigs and Poultry to the broiler productive chain, were formulated questions about: Knowledge and use of developed technologies by the Unit, importance attributed to those technologies, Unit contribution degree to the chain, existence of a distancing between Embrapa and the chain, distancing degree, interaction forms of Embrapa with the chain, forms of identifying demands and orientation of the research efforts.

To know if the developed technologies by the Unit are known and used by the diverse links of the chain were selected five technologies for each link and requested that they mentioned which one of the technologies they know and the importance degree of those technologies.

Agricultural industries: From the total of 27 respondents, two did not know to evaluate. The rest mentioned the technologies: compost separator for composting of bird carcass, the thermal environmental conditioning of aviaries and broiler production cost calculus. Those three technologies were considered important by the respondents, which attributed importance degree ranged between 5 and 7 , in a scale from 1 to 7 .

Equipments: Among the 30 respondents, five did not answer the question. The rest mentioned two technologies: Curtain and light program for broilers, which attributed importance degree was 6 and the Thermal environmental conditioning of aviaries, with importance degree of 7 .

Genetics: Of the 12 respondents, 2 did not answer the question. Of the respondents that answered, only 2 affirmed to know or use the technologies: Identification of the genomic regions in the chromosomes of the hen associated with characteristics of performance, carcass and weight of the organs (importance degree of 5), and Analysis of multiple characteristics for mapping of QTL in hens, with the interviewed not attributing importance degree.

Nutrition: From the total of the 52 respondents, only one did not answer that question. The most mentioned technologies are: Utilization of enzyme in diets based in corn and soy bran for broilers (degree 7) and the Chemical composition and values of metabolisable energy for broilers (degree 7).

Health: Of the 22 respondents, seven did not answer that question, the rest only mentioned the technology Monitoring of bird serum, resistance to antimicrobials and genotypes of Salmonella spp., isolated from commercial broiler aviaries, for which four attributed importance degree of 5 .

For the respondents, the main functions of Embrapa Pigs and Poultry in the chain are: "To develop technologies to meet the specific demands of the chain" (71.63\%) and "Applied Science sharing the gains of the innovation in the chain" (58.16\%).
Regarding the contribution degree of the institution to the chain, there was not a cohesive opinion among the groups of respondents. The attributed contribution degree, in a scale from 1 (very low) to 7 (very high), ranged between three (8.13\%) and seven (24.39\%). For $21.95 \%$ of the respondents, the institution contribution degree is five, with the same percentage of respondents attributing a degree of 6 to that question. Among all the links, the contribution of Embrapa is more perceived by the nutrition link, where $30 \%$ of the respondents attributed a degree of 7 and 19\% attributed a degree of 6 .

The best forms for Embrapa to identify research demands are by means of the participation in events of the sector (73.05\%), regular consultations to specialists and users of the technologies (65.96\%) and the intensification of the interpersonal relationship (65.71\%). Regarding the research efforts, $76.34 \%$ of the respondents believe that they must be directed to the production stage.

The existence of a distancing between Embrapa and the diverse links of the chain is perceived by $80.53 \%$ of the respondents (Figure 4 ).

\section{Distancing between Embrapa and the chain}

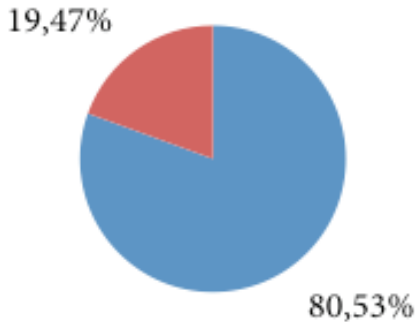

Figure 4: Distancing between Embrapa and the chain Source: Field research

Such distancing is more strongly perceived in the health link (94.4\%). In the other links, the percentages ranged between $74.4 \%$ (Nutrition) and $77.8 \%$ (Genetics). To reduce the distancing and promoting a larger interaction with the chain, the institution must "Promote regular encounters with the companies to discuss the demands" (80.14\%) and “To develop partnership research projects" (72.14\%).

Analyzing the low rate of adoption of the generated technologies by the institution and the distancing existing between Embrapa and the diverse links of the chain, was perceived the need of looking for a new TT model which allows to promote a larger interaction with the chain to know its real demands and enable the joint development of applied technologies that meet those demands, thereby increasing the adoption rate of the generated technologies and, therefore, its legitimating before its users.

In this context, that research had the objective of proposing and validating a TT model that can meet those needs appointed by the re- 
search. The proposed model was the creation of a Poultry Research Observatory. Next we will present the result of the validation of that model by the diverse links of the broiler productive chain.

\section{Validation of the proposed model}

To validate the proposed model, were elaborated the following questions: Do you consider important the creation of an observatory as a form of identifying the demands of the chain and extend the interaction between Embrapa Pigs and Poultry and the chain; which would be the role of Embrapa Pigs and Poultry in that observatory; which would be the role of the companies in that observatories; which links of the chain must take part of the observatory; how the observatory may interact with the diverse links of the chain; the observatory must be formalized; Do you (or your company) will take part of the observatory.

The creation of the observatory was approved by $96.77 \%$ of the respondents. The approval rate in the agricultural industries and genetics companies was $100 \%$. In the link of equipments, the approval percentage was $88.90 \%$; in the link of Nutrition was $96.30 \%$ and in the link of Health $95 \%$.

Regarding the role of Embrapa Pigs and Poultry in the observatory, for $86.4 \%$ of the respondents, the institution must coordinate the observatory. The companies, in turn, must participate (84.8\%) and demand $(56.8 \%)$ from the observatory.

The links of the chain that must have priority participation in the observatory are the agricultural industries (87.2\%), nutrition companies (78.4\%), health companies (73.6\%), equipment companies $(69.6 \%)$ and genetics companies (67.2\%). Besides those companies, must also take part the research institutions (65.6\%) and universities (62.4\%).

The suggested form for interaction of the observatory with the diverse links of the chain was the execution of regular encounters with representatives of the links of the chain. (81.6\%). Only the link of health suggested the use of an online interaction platform for doubts and suggestions (73.70\%), as interaction form.

According to $99.17 \%$ of the respondents, the observatory must be formalized. Only $5.3 \%$ of the respondents of the link of health believe that there is no need for formalization.

There was also a great acceptance from the respondents in taking part of the observatory. From the total of respondents $96.77 \%$ were willing to participate. The participation rate of the links was as follows: Agricultural industries (96.30\%), Equipments (96\%), Genetics (88.90\%), Nutrition (97.70\%) and Health (100\%).

\section{Conclusion}

The low adoption rate of the developed technologies by Embrapa Pigs and Poultry, according to the reviewed literature and the results of this survey, can be attributed, by the form how those results are transferred and by the possibility of the generated technology does not meets the demands of the chain.
In both cases, that result can be attributed to the lack of interaction between the institution and the technology users. The TT current model does not provide interaction mechanisms with the chain, to identify its demands, which may result in a poorly formulated research problem and, consequently in technologies without practical application.

The model proposed in this survey aims to increase the interaction between the technology developers and the users, suggesting the technology as a result of a two-way interactive process (non-linear) with constant and simultaneous exchange of ideas between the involved individuals. The TT role in that model will be the consultation to customers, formalization of partnerships, distribution of royalties and patenting/licensing of the technology. Such approximation with the chain will allow knowing better the existing problems and discussing together the best form of solving them. That way, knowing the problems of the chain and developing practical solutions will help Embrapa to increasingly legitimate itself before the society.

\section{References}

Atkinson, R., Beachy, R., Conway, G., Cordova, F., Fox, M. Holbrook, K.,Klessig, D., McCormick, L., McPherson, P., Rawlings, H., Rapson, R. Vanderhoef, L., Wiley, J. \& Young, C. (2003). Public Sector Collaboration for Agricultural IP Management. Science. 301(5630) 174-175.

Bassi, N.S.S. \& Silva, C.L. (2014). As estratégias de divulgação científica e transferência de tecnologia utilizada pela Empresa Brasileira de Pesquisa Agropecuária-Embrapa. Interações 15(2), 361-372.

CEPEA - Centro de Estudos Avançados em Economia. (2015). Retrieved from: http://cepea.esalq.usp.br/pib/ .

Eldred, W. \& Mcgrath, M. E. (1997). Commercializing new technology I. Research Technology Management, 40(1), pp.41-47.

Empresa Brasileira de Pesquisa Agropecuária - EMBRAPA. (2015) Retrieved from: http://www.embrapa.br/. (2008). Secretaria de Gestão e Estratégia. V Plano Diretor da Embrapa 2008-2011-2023. Brasília, DF.

Fujisaka, S. (1994). Learning from six reasons why farmers do not adopt innovations intended to improve sustainability of upland agriculture. Agricultural Systems, Barking, 46 (4), pp.409-425.

Garnica, L. A. \& Torkomian, A. L. V. (2009). Gestão de tecnologia em universidades: uma análise do patenteamento e dos fatores de dificuldade e de apoio à transferência de tecnologia no Estado de São Paulo, Gest. Prod., São Carlos, 16(4), pp.624-638.

Grant Thorton International. (2015). International Business Report. Focus on Brazil. Retrieved from: http://www.grantthorntonibos.com/ Reports/2010/index.asp.

Johnson,, B. B. (1996). Serviços públicos no Brasil: mudanças e perspectivas. São Paulo: Edgard Blucher. 
Kim, L. (2005). Da imitação à inovação: a dinâmica do aprendizado tecnológico da Coréia. Campinas, SP: Unicamp, 388 p.

Krieger, E. \& Galembeck, F. (1996). A capacitação brasileira para a pesquisa. In Schwartzman, S., Bertero, C.O., Krieger, E. M. (Eds). Ciência e tecnologia no Brasil: A capacitação brasileira para a pesquisa científica e tecnológica (pp.1-18). Rio de Janeiro; Editora da Fundação Getúlio Vargas.

Pineiro, Martin. (2007). Agricultural technology transfer to developing countries and the public sector. Retrieved from: file:///D:/perfil/Documents/Documentos\%20outro\%20perfil/bibliografia\%20por\%20 assunto/foresight/Agricultural\%20technology $\% 20$ transfer\%20to $\% 20$ developing\%20countries\%20and\%20the\%20public\%20sector.htm

Povoa, A, L.M.C. (2008). Patentes de universidades e institutos públicos de pesquisa e a transferência de tecnologia para empresas no Brasil (Tese de doutorado). Universidade Federal de Minas Gerais, Belo Horizonte, MG, Brasil.
Schaun, N. M. (1981). Difusão de tecnologia no Centro Nacional de Milho e Sorgo. Sete Lagoas: EMBRAPA CNPMS, 27 p.

Schwartzman, S. (1996). Ciência e Tecnologia no Brasil: A capacitação brasileira para a pesquisa científica e tecnológica. Rio de Janeiro. Fundação Getúlio Vargas, pp.287-320.

Tagliari, P. S. (1984). Analysis of the communication linkages between the research and extensions agencies and evaluation of the research publications in the State of Santa Catarina, Brazil. 1984. 207 p. M.Sc. thesis (Master of science agricultural journalism) - University of Wisconsin, Madison, 1984.

Wildner, L. P., Nadal, R. \& Silvestro, M. (1993). Metodologia para integrar a pesquisa, a extensão rural e o agricultor. Agropecuária Catarinense. Florianópolis, 6 (3), pp.37-47. 